\section{Coastal erosion and insurance}

SIR - Barbara Culliton's leading article "Save the beaches, not the buildings" (Nature 357, 535; 1992) is uninformed and self-contradictory.

Culliton writes ". . . the US Congress years ago agreed to provide flood insurance, at federal expense, for home owners whose beachfront property is damaged by storms and erosion". Congress did no such thing. It agreed to create an interest-earning fund to underwrite the risk to private insurers who provided such insurance. Congress has often chosen, in the public interest, to underwrite insurance that private insurers are reluctant to provide. An obvious example is bank-deposit insurance.

The distinction between underwriting insurance and providing it at federal expense might seem insignificant, except for the following. The federal government, and by extension the taxpayer, pays nothing for flood damage to private beachfront property. In other words, any claims for flood damage have been covered by the private insurers. It is worth adding that the overwhelming majority of the flood-damage claims are made not by the owners of beachfront property but by those of river-valley property. Hence the plaint that "taxpayers from the cornbelt [support] Eastern beach lovers" would seem to be the reverse of what actually happens.

Culliton inveighs against the efforts of beachfront communities, such as Ocean City, Maryland, to replenish their eroding beaches. There is no relation between such efforts and federally underwritten flood insurance. Where beachfront communities replenish beaches, they are doing so for the benefit not of beachfront home-owners but of members of the public who use the beaches for recreation.

As for self-contradiction, Culliton asserts that beaches are notoriously unstable and that it is folly for people to build on them. But if the beaches are unstable, what is meant by "Save the beaches, not the buildings"? As she objects to efforts to stabilize public beaches, what she has in mind for the beaches is presumably letting nature have its way. Whatever the wisdom of such a policy, it would seem to be an odd definition of saving. To be sure, there were those who felt that the great fires in Yellowstone National Park were a natural phenomenon that should be allowed to run its course. Few agreed with them.

On the whole, Culliton seems to hope that in time all beachfront homes will be bulldozed and the beaches will be left in their pristine condition. This is an arcadian vision unconnected with reality. Responsible beachfront home owners, living on a coastline extending from Maine to Florida, from Florida to Texas and from California to Washington, number in the hundreds of thousands. The notion that they can be made to disappear is no more reasonable than to expect that the entire country will one day revert to its pre-Columbian state. This being so, it hardly seems fair to deny citizens who live on the coast the right to insurance that costs the taxpayer nothing.

Dennis Flanagan

12 Gay Street,

New York, New York 10014, USA

SIR - Coastal erosion is not a simple universal continuing process at all. Where it occurs, it is usually the result of a combination of many processes, and a combination that changes significantly from place to place and site to site.

Hurricanes do tend to cause erosion, but not all of them. It depends upon their translational celerity, but again, for most of the time, the storm erosion is reversed during subsequent fine weather, and the beach returns. Then all beaches, as well as coastal barriers, are not so much "unstable" as mobile. Beaches absorb wave energy by allowing their sediments to move. Pressure is exerted against the waves by the weight of the sediments being moved through a distance. There is also much evidence available that suggests that the US eastern seaboard barrier islands are migrating, generally quite slowly, not because of wave erosion but from the natural sinking of the edges of the Atlantic plates and/or the dead weight of the vast volumes of sediments deposited on the continental shelf by major rivers.

There is also highly convincing evidence that much and often most of the US Atlantic and Texas coast barrier island erosion is manmade and certainly not the fault of "natural erosion" nor the coastal landowners who wish to live there. The major beach erosion in Florida has been caused by dredging, usually by the federal government, of barrier island crossings to deepen them for navigation. Until very recently, the dredged material, which originally came from the beaches anyway, was simply dumped offshore in deep water.

Similar evidence from Texas and southern California demonstrates that their beaches and islands are retreating because natural sand that once maintained the beaches, by being discharged onto them during floods, is trapped in state and federal constructed irrigation and water supply dams that cut off natural sediment supply. And the extreme erosion to Folly Island, South
Carolina, is most probably the result of the trapping capacity of the great jetties leading to Charleston Harbor and their subsequent dredging, as in Florida. In fact, in Florida itself, well over half the crossings now being dredged are not natural, but manmade in the past by government bodies. The dredged jettied navigation entrance to Miami Port is still called Government Cut.

The selection of Ocean City, Maryland, to denigrate the value of beach nourishment is an example of slanting evidence by picking a worst case. There are many more cases where artificial nourishment, not just 'dumping', has been highly beneficial and cost effective. The major nourishments carried out in Pinellas, Broward and Dade Counties in Florida have been stunning successes, and repaired the damage done by earlier disposal offshore of dredged material. It is similarly notable that the dramatic sea-level rise of 3.5 metres in 20 years comes from an obsolete approximation arrived at by the US National Academy of Sciences in 1987. Current research much of which has been reported in Nature - is now beginning to downgrade this type of estimate, and the climate models used are themselves still open to significant modification as more data become available. We simply cannot yet make any reliable predictions.

"Sensible coastal conservation" is much more than picking out coastal landowners as villains. Coastal conservation's first step must surely be to identify the causes of the erosion, and for much of the United States the causes may be found to be manmade, but manmade by others than the beachfront land-owners who want to live there. There may be sound reasons for reviewing coastal flooding insurance and the impact of FEMA, but let us have a balanced view of the whole problem of cause and effect first, before picking on the poor shorefront residents and making them the only scapegoats. Even seawalls need not, and often do not, destroy beaches unless there are other applied erosive forces also affecting the coast, and not all of them are natural.

\section{A. W. Sam Smith}

Coastal Processes and Research, 5 Ilkima Avenue, Broadbeach Waters, Queensland 4218, Australia

\section{Mark Kac}

SIR - In "Energy levels by path integration" (Nature 358, 707; 1992), for Kacs read Kac, passim. A singular mathematician indeed!

Nicholas J. Cox

Department of Geography,

The University Durham, DH1 3LE, UK 